\title{
LEGALITAS COVER SONG YANG DIUNGGAH KE AKUN YOUTUBE
}

\author{
${ }^{1}$ Hasrina Rahma; ${ }^{2}$ Yati Nurhayati \\ Fakultas Hukum, Universitas Islam Kalimantan MAB \\ Jl.Adhyaksa No.2, Kota Banjarmasin 70123 \\ Email: yatinurhayati1904@yahoo.com \\ Scopus ID: 6507923727
}

\begin{abstract}
Currently, in Indonesian community, especially among the millennial, YouTube is very popular. Through this media, they make various videos, one of which is song covers. In the video they sang the song in several versions for instances an original way like the original singer, there was also an arrangement of the music, and those who sang in their respective voice colors. The purpose of this research is to study, first, whether the re-arrangement of song includes infringement of the copyright and how is the legal protection for the original owner of the cover song uploaded to YouTube. The method used in this research is normative research, using literature research that refers to the legal norms contained in legislation. The results of the study found that it is necessary to distinguish between cover songs and arrangements. Cover songs through rearrangement of songs does not include copyright infringement while cover songs without arrangement can be done as long as it has a license and royalty payment, otherwise the song cover is a violation of the law.
\end{abstract}

Keywords: Copyrights; Cover; Music; YouTube

\begin{abstract}
Abstrak
Saat ini masyarakat Indonesia khususnya dikalangan kaum milenial sedang marakmaraknya menggunakan YouTube. Lewat media tersebut mereka membuat berbagai video salah satunya cover lagu. Dalam cover lagu tersebut mereka menyanyikan ulang lagu dengan cara orisinil seperti penyanyi aslinya, ada juga yang mengaransemen musiknya, dan adapula yang menyanyikan dengan warna suaranya masing- masing. Tujuan dari penelitian ini adalah untuk mengetahui, pertama apakah aransemen ulang lagu milik orang lain termasuk pelanggaran hak cipta kedua, bagaimana perlindungan hukum bagi pemilik lagu yang dicover dan diunggah ke youtube. Metode yang digunakan dalam penelitian ini adalah penelitian normatif yaitu penelitian hukum kepustakaan yang mengacu pada norma hukum yang terdapat dalam peraturan perundang-undangan. Hasil penelitian ditemukan bahwa perlu dibedakan cover lagu dan aransemen. Tindakan cover melalui aransemen ulang lagu milik orang lain tidak termasuk pelanggaran hak cipta sedangkan cover lagu tanpa aransemen dapat dilakukan asalkan memiliki izin lisensi dan pembayaran royalti, jika tidak maka cover lagu tersebut merupakan pelanggaran hukum.
\end{abstract}

Kata Kunci: Hak Cipta; Cover; Musik; YouTube 


\section{PENDAHULUAN}

Kekayaan intelektual merupakan kreativitas yang dihasilkan dari olah pikir manusia dalam rangka memenuhi kebutuhan dan kesejahteraan hidup manusia. Penemuan (inventions) dan hasil karya cipta dan seni (art and literary work) memberikan pengaruh yang besar terhadap kehidupan manusia. Ketika suatu hasil kreativitas manusia digunakan untuk tujuan komersial, muncullah pemikiran bahwa perlu adanya suatu bentuk penghargaan khusus terhadap karya intelektual seseorang dan hak yang muncul dari karya itu.

Kekayaan kekayaan intelektual (HKI) adalah padanan kata yang biasa digunakan untuk intellectual property rights (IPR), yakni hak yang timbul dari hasil olah pikir yang menghasilkan suatu produk atau proses yang berguna untuk manusia. Pada intinya kekayaan intelektual adalah hak untuk menikmati secara ekonomis hasil dari suatu kreativitas intelektual. Objek yang diatur dalam kekayaan intelektual berupa karya-karya yang timbul atau lahir karena kemampuan intelektual manusia. ${ }^{1}$ Di Indonesia sistem hukum HKI tersebut sudah muncul sejak Pemerintah Kolonial Hindia Belanda yaitu

\footnotetext{
Wikipedia "Kekayaan Inelektual." https://id.wikipedia.org/wiki/Kekayaan_intelektual (diakses pada tanggal 20 Oktober 2019 pukul 07.00 WITA)
}

dengan dikeluarkannya peraturan HKI yang meliputi Auteurswet 1912 Stb No.600 bagi perlindungan hak cipta, Reglement Industriele Eigendom Kolonien Stb No. 545 jo. Stb No. 214 mengenai perlindungan hak merek, dan Octrooweit 1910 S.No. 33 yis S.11-33, S mengenai perlindungan hak paten. ${ }^{2}$

Hak Cipta (dengan logo atau lambang internasional: (C), Unicode: U+00A9) adalah hak eksklusif Pencipta atau Pemegang Hak Cipta untuk mengatur penggunaan hasil penuangan gagasan atau informasi tertentu. Pada dasarnya, hak cipta merupakan "hak untuk menyalin suatu ciptaan". Hak cipta dapat juga memungkinkan pemegang hak tersebut untuk membatasi penggandaan tidak sah atas suatu ciptaan. Pada umumnya pula, hak cipta memiliki masa berlaku tertentu yang terbatas.

Hukum yang mengatur hak cipta biasanya hanya mencakup ciptaan yang berupa perwujudan suatu gagasan tertentu dan tidak mencakup gagasan umum, konsep, fakta, gaya, atau teknik yang mungkin terwujud atau terwakili di dalam ciptaan tersebut. Sebagai contoh, hak cipta

\footnotetext{
${ }^{2}$ Direktorat Jenderal Kekayaan Intelektual "Sejarah Perkembangan Perlindungan Kekayaan Intelektual (KI)", dapat diakses pada https://dgip.go.id/sejarah-perkembanganperlindungan-kekayaan-intelektual-ki (diakses pada tanggal 20 Oktober 2019 pukul 7.22 WITA)
} 
yang berkaitan dengan tokoh kartun Miki Tikus melarang pihak yang tidak berhak menyebarkan salinan kartun tersebut atau menciptakan karya yang meniru tokoh tikus tertentu ciptaan Walt Disney tersebut, tetapi tidak melarang penciptaan atau karya seni lain mengenai tokoh tikus secara umum. ${ }^{3}$

Hak cipta merupakan salah satu jenis hak kekayaan intelektual, tetapi hak cipta berbeda secara mencolok dari hak kekayaan intelektual lainnya (seperti paten, yang memberikan hak monopoli atas penggunaan invensi), karena hak cipta bukan merupakan hak monopoli untuk melakukan sesuatu, melainkan hak untuk mencegah orang lain yang melakukannya.

Salah satu hak cipta di bidang seni adalah karya cipta lagu atau musik. Hampir semua orang di dunia menyukai lagu dan musik. Seiring dengan perkembangan ilmu pengetahuan dan teknologi, produk-produk yang berkaitan dengan ciptaan lagu atau musik pun telah berperan bagi peningkatan perekonomian masyarakat.

Lagu dan musik dalam kehidupan sehari-hari dipergunakan di berbagai kesempatan baik itu didengar, diperdengarkan, disiarkan, dipertunjukkan, serta disebarkan. Media yang digunakan bukan hanya televisi dan radio kini telah berkembang menggunakan handphone. Sebagian penggunaan lagu dan musik tersebut selau disertai dengan aktivitas ekonomi, sebagai contoh membeli lagu di handphone melalui aplikasi Itunes dan menonton video musik melalui aplikasi YouTube. Perkembangan teknologi terkait sarana untuk menikmati lagu dan musik tentu membawa dampak positif dan negatif.

Dampak positifnya adalah masyarakat semakin mudah untuk menikmati musik, juga memudahkan pencipta dalam hal mempromosikan karya-karyanya, dampak negatifnya banyak orang yang justru menyalahgunakan teknologi untuk kepentingan pribadi seperti melakukan pembajakan, dan yang terbaru adalah mendapatkan keuntungan berupa uang dari membuat video cover yang diunggah ke YouTube. Fenomena pelanggaran terhadap Hak Cipta khususnya berupa pengumuman musik atau lagu saat ini seolah-olah berlangsung tanpa ada penyelesaian hukum yang berarti. Banyak pelaku usaha dalam kegiatan komersial usahanya menyiarkan musik atau lagu tanpa membayar royalti atau meminta izin dari penciptanya. Di Indonesia secara nasional hak cipta diatur 
dalam Undang-Undang Nomor 28 Tahun 2014 Tentang Hak Cipta. ${ }^{4}$

Saat ini banyak sekali orang salah satunya masyarakat Indonesia khususnya dikalangan kaum milenial sedang marakmaraknya menggunakan social media salah satunya youtube. Lewat media tersebut mereka membuat berbagai video salah satunya cover lagu yang sedang ramai- ramainya dilakukan kaum milenial. Dalam cover lagu tersebut mereka menyanyikan ulang lagu dengan cara orisinil seperti penyanyi aslinya, ada juga yang mengaransemen musiknya, dan adapula yang menyanyikan dengan warna suaranya masing- masing.

Adapun dalam artikel kali ini akan membahas tentang cover version yang diungah ke akun Youtube. Cover version berkaitan dengan hak cipta dikarenakan menyanyikan kembali suatu karya yang sudah ada wujud nyatanya.

\section{RUMUSAN MASALAH}

Berdasarkan latar belakang diatas, dalam artikel ini akan membahas:

1. Apakah aransemen ulang lagu milik orang lain termasuk pelanggaran hak cipta?

\footnotetext{
${ }^{4}$ Anak Agung Mirah Satria Dewi, (2017), "Perlindungan Hukum Hak Cipta Terhadap Cover Version Lagu di Youtube", Jurnal Magister Hukum Udayana, Vol. 6, No. 4, hlm. 509- 511
}

2. Bagaimana perlindungan hukum bagi pemilik lagu yang dicover dan diunggah ke youtube?

\section{METODE PENELITIAN}

Ilmu hukum berusaha untuk menampilkan hukum secara integral sesuai dengan kebutuhan kajian ilmu hukum itu sendiri, sehingga metode penelitian dibutuhkan untuk memperoleh arah penelitian yang komprehensif. ${ }^{5}$ Metode yang digunakan dalam penelitian ini adalah metode penelitian normative yaitu metode yang penelitian normatif (Normative Legal Research) yaitu penelitian hukum kepustakaan yang mengacu pada norma hukum yang terdapat dalam peraturan perundang-undangan. ${ }^{6}$ Dalam hal ini pendekatan dilakukan dengan menggunakan pendekatan perundangundangan.

\section{PEMBAHASAN}

Karya cipta dalam bentuk digital memang sangat mudah untuk diduplikasi dan hasil atas perbuatan tersebut juga nyaris tidak dapat dibedakan dengan aslinya. Tidak hanya itu, orang pun

5 Yati Nurhayati, (2013), "Perdebatan Antara Metode Normatif Dengan Metode Empirik Dalam Penelitian Ilmu Hukum Ditinjau Dari Karakter, Fungsi, dan Tujuan Ilmu Hukum" Jurnal Al Adl, Vol 5, No 10, hlm.15

6 Soerjono Soekamto dan Sri Mamudji, (2006), Penelitian Hukum Normatif : Suatu Tinjauan Singkat, cet 9, Jakarta : Rajawali Press, hlm 23. 
kemudian dapat melakukan modifikasi terhadap hasil penggandaan dan mendistibusikannya ke seluruh dunia dengan nyaris tanpa biaya. Di satu sisi, hal ini tentu membuat sangat mudah bagi hampir semua orang untuk melanggar hak cipta orang lain dalam skala yang sangat besar, tetapi di sisi lain sangat sulit bagi pemilik hak cipta untuk mengetahui terjadinya pelanggaran, mengenali, atau pun kemudian melakukan upaya hukum. ${ }^{7}$ Adapun kemungkinan keuntungan yang didapat apabila mengunggah video ke akun Youtube antara lain menjadi terkenal, mendapatkan penghasilan dari hasil penonton video (viewers) maupun dari pengikut (subscriber). Sehingga memang ada hasil ekonomi yang didapatkan dari video tersebut.

Pengaturan Terkait Cover Lagu Yang

\section{Diunggah Ke Youtube}

Ruang lingkup perlindungan hukum dalam Undang Undang No. 28 Tahun 2014 tentang Hak Cipta diatur pada pasal 40 yakni Ciptaan dalam bidang ilmu pengetahuan, seni, dan sastra, terdiri atas:

a. buku, pamflet, perwajahan karya tulis yang diterbitkan, dan semua hasil karya tulis lainnya;

${ }^{7}$ Isnaini, Yusran. (2009). Hak Cipta dan Tantangannya di Era Cyber Space. Bogor: Ghalia Indonesia, hlm. 28. b. ceramah, kuliah, pidato, dan

Ciptaan sejenis lainnya;

c. alat peraga yang dibuat untuk kepentingan pendidikan dan ilmu pengetahuan;

d. lagu dan/atau musik dengan atau tanpa teks;

e. drama, drama musikal, tari, koreografi, pewayangan, dan pantomim;

f. karya seni rupa dalam segala bentuk seperti lukisan, gambar, ukiran, kaligrafi, seni pahat, patung, atau kolase;

g. karya seni terapan;

h. karya arsitektur;

i. peta;

j. karya seni batik atau seni motif lain;

k. karya fotografi

1. Potret;

m. karya sinematografi;

n. terjemahan, tafsir, saduran, bunga rampai, basis data, adaptasi, aransemen, modifikasi dan karya lain dari hasil transformasi;

o. terjemahan, adaptasi, aransemen, transformasi, atau modifikasi ekspresi budaya tradisional;

p. kompilasi Ciptaan atau data, baik dalam format yang dapat dibaca dengan Program Komputer maupun media lainnya; 
q. kompilasi ekspresi budaya tradisional selama kompilasi tersebut merupakan karya yang asli;

r. permainan video; dan

s. Program Komputer.

Lagu terdapat pada pasal 40 ayat (1) huruf D bahwa lagu dan/atau musik dengan atau tanpa teks merupakan hak cipta yang dilindungi. Pada permasalahan kali ini apakah tindakan mencover lagu milik orang lain termasuk pelanggaran hak cipta? Untuk menjawab pertanyaan ini maka merujuk pada pasal 40 ayat (1) huruf n terkait aransemen. Jika lagu atau musik tersebut dicover dengan mengubah beberapa komponen kunci sehingga menimbulkan hasil transformasi music. Maka hal ini bukanlah pelanggara hak cipta melainkan suatu ciptaan baru yang bahkan dilindungi oleh Undang-Undang Hak Cipta.

Adapun ciptaan ini dilindungi sebagai ciptaan tersendiri dengan tidak mengurangi Hak Cipta atas ciptaan asli. Pelindungan sebagaimana dimaksud, termasuk pelindungan terhadap Ciptaan yang tidak atau belum dilakukan Pengumuman tetapi sudah diwujudkan dalam bentuk nyata yang memungkinkan Penggandaan Ciptaan tersebut. ${ }^{8}$

${ }^{8}$ Pasal 40 ayat (2) dan ayat (3) Undang Undang No. 28 Tahun 2014 tentang Hak Cipta
Namun jika cover lagu tersebut dilakukan tanpa adanya aransemen atau transformasi lainnya, maka diperlukan adanya lisensi dari pemegang hak cipta aslinya. Lebih lanjut dalam industri musik, dari sudut perlindungan hak cipta dibedakan antara komposisi musik/lagu (music composition) dan rekaman suara (sound recordings).

Komposisi musik terdiri dari musik, termasuk di dalamnya syair/lirik. Komposisi musik dapat berupa sebuah salinan notasi atau sebuah rekaman awal (phonorecord) pada kaset rekaman atau CD. Komposer/pencipta lagu dianggap sebagai pencipta dari sebuah komposisi musik. Sementara itu, rekaman suara (sound recording) merupakan hasil penyempurnaan dari serangkaian suarasuara baik yang berasal dari musik, suara manusia dan atau suara-suara lainnya. Dianggap sebagai pencipta dari sound recording adalah pelaku/performer (dalam hal pertunjukan) dan atau produser rekaman (record producer) yang telah memproses suara-suara dan menyempurnakannya menjadi sebuah rekaman final. Sehingga hak cipta pada sebuah rekaman suara tidak dapat disamakan dengan, atau tidak dapat menggantikan hak cipta pada komposisi 
musiknya yang menjadi dasar rekaman suara tersebut.

Untuk lagu-lagu cover yang diciptakan tanpa aransemen ulang untuk tujuan komersial tadi, pencantuman nama penyanyi asli saja pada karya cover tentu tidak cukup untuk menghindari tuntutan hukum pemegang hak cipta. Agar tidak melanggar hak cipta orang lain, untuk mereproduksi, merekam, mendistribusikan dan atau mengumumkan sebuah lagu milik orang lain, terutama untuk tujuan komersial, seseorang perlu memperoleh lisensi. Lisensi secara umum dapat diartikan pemberian izin, hal ini termasuk dalam sebuah perjanjian. ${ }^{9}$ Lisensi dari pencipta/pemegang hak cipta sebagai berikut:

1. Lisensi atas Hak Mekanikal (mechanical rights), yakni hak untuk menggandakan, mereproduksi (termasuk mengaransemen ulang) dan merekam sebuah komposisi musik/lagu pada $\mathrm{CD}$, kaset rekaman dan media rekam lainnya; dan atau

2. Hak Mengumumkan (performing rights), yakni hak untuk mengumumkan sebuah lagu/komposisi musik, termasuk menyanyikan,

9 Wikipedia "Lisensi." Dapat diakses secara online https://id.wikipedia.org/wiki/Lisensi diakses tanggal 02 November 2019 pukul 18.48 WITA memainkan, baik berupa rekaman atau dipertunjukkan secara live (langsung), melalui radio dan televisi, termasuk melalui media lain seperti internet, konser live dan layanan-layanan musik terprogram.

Royalti atas mechanical right yang diterima dibayarkan oleh pihak yang mereproduksi atau merekam langsung kepada pemegang hak (biasanya perusahaan penerbit musik (publisher) yang mewakili komposer/pencipta lagu). Sementara pemungutan royalti atas pemberian performing rights di Indonesia dilakukan oleh Lembaga Manajemen Kolektif (LMK) berdasarkan kesepakatan antara pencipta dan lembaga tersebut.

WAMI (Wahana Musik Indonesia) dan YKCI (Yayasan Karya Cipta Indonesia) adalah dua dari beberapa LMK di Indonesia yang saat ini aktif menghimpun dan mendistribusikan royalti dari hasil pemanfaatan performing rights untuk diteruskan kepada komposer/ pencipta lagu dan publisher. ${ }^{10}$

Adapun dalam Undang Undang No. 28 tahun 2014 tentang hak cipta pasal 49

${ }^{10}$ Hukumonline "Apakah Menyanyikan Ulang Lagu Orang Lain Melanggar Hak Cipta?" https://www.hukumonline.com/klinik/detail/ulasa n/lt506ec90e47d25/apakah-menyanyikan-ulanglagu-orang-lain-melanggar-hak-cipta/ (diakses tanggal 21 October 2019 pukul 09.30 WITA) 
ayat (1) Penggandaan sementara atas Ciptaan tidak dianggap pelanggaran Hak Cipta jika Penggandaan tersebut memenuhi ketentuan:

a. pada saat dilaksanakan transmisi digital atau pembuatan Ciptaan secara digital dalam media penyimpanan;

b. dilaksanakan oleh setiap Orang atas izin Pencipta untuk mentransmisi Ciptaan; dan

c. menggunakan alat yang dilengkapi mekanisme penghapusan salinan secara otomatis yang tidak memungkinkan Ciptaan tersebut ditampilkan kembali

Pada ayat (2) dijabarkan bahwa setiap Lembaga Penyiaran dapat membuat rekaman sementara tanpa izin Pencipta atau Pemegang Hak Cipta untuk tujuan aktivitasnya dengan alat dan fasilitasnya sendiri. Selanjutnya pada ayat (3) Lembaga Penyiaran wajib memusnahkan rekaman sementara sebagaimana dimaksud pada ayat (2) dalam waktu paling lama 6 (enam) bulan sejak pembuatan atau dalam waktu yang lebih lama dengan persetujuan Pencipta. Selanjutnya pada ayat (4) dijelaskan bahwa Lembaga Penyiaran dapat membuat 1 (satu) salinan rekaman sementara yang mempunyai karakteristik tertentu untuk kepentingan arsip resmi. ${ }^{11}$

\section{Perlindungan Hukum Bagi Pemilik Lagu Yang Cover dan Diunggah ke YouTube.}

Perlindungan hukum adalah segala upaya pemenuhan hak dan pemberian bantuan untuk memberikan rasa aman kepada saksi dan/atau korban, perlindungan hukum korban kejahatan sebagai bagian dari perlindungan masyarakat, dapat diwujudkan dalam berbagai bentuk, seperti melalui pemberian restitusi, kompensasi, pelayanan medis, dan bantuan hukum. ${ }^{12}$

$\begin{array}{ccc}\text { Menurut } & \text { Satjipto } & \text { Raharjo } \\ \text { mendefinisikan } & \text { perlindungan } & \text { hukum } \\ \text { adalah memberikan pengayoman } & \text { kepada }\end{array}$
hak asasi manusia yang dirugikan orang lain dan perlindungan tersebut diberikan kepada masyarakat agar mereka dapat menikmati semua hak-hak yang diberikan oleh hukum. ${ }^{13}$ Philipus M. Hadjon berpendapat bahwa Perlindungan Hukum adalah perlindungan akan harkat dan martabat, serta pengakuan terhadap hakhak asasi manusia yang dimiliki oleh

\footnotetext{
${ }^{11}$ Pasal 49 Undang Undang No. 28 Tahun 2014 tentang Hak Cipta

12 Soerjono Soekanto, (1984), Pengantar Penelitian Hukum, Jakarta: UI Press, hlm 133

${ }^{13}$ Satjipto Rahardjo, (2000), Ilmu hukum, Bandung: Citra Aditya Bakti, Cetakan ke-V, hlm. 53.
} 
subyek hukum berdasarkan ketentuan hukum dari kesewenangan. ${ }^{14}$ Sedangkan menurut Setiono, perlindungan hukum adalah tindakan atau upaya untuk melindungi masyarakat dari perbuatan sewenang-wenang oleh penguasa yang tidak sesuai dengan aturan hukum, untuk mewujudkan ketertiban dan ketentraman sehingga memungkinkan manusia untuk menikmati martabatnya sebagai manusia. ${ }^{15}$

Menurut Muchsin, perlindungan hukum merupakan kegiatan untuk melindungi individu dengan menyerasikan hubungan nilai-nilai atau kaidah-kaidah yang menjelma dalam sikap dan tindakan dalam menciptakan adanya ketertiban dalam pergaulan hidup antar sesama manusia. ${ }^{16}$

\section{Menurut Philipus M. Hadjon} Perlindungan Hukum adalah Sebagai kumpulan peraturan atau kaidah yang akan dapat melindungi suatu hal dari hal lainnya. Berkaitan dengan konsumen, berarti hukum memberikan perlindungan terhadap hak-hak pelanggan dari sesuatu

14 Philipus M. Hadjon, (1987), Perlindungan Bagi Rakyat diIndonesia, Surabaya: Bina Ilmu, hlm. 1-2.

15 Setiono, (2004), Rule of Law (Supremasi Hukum), Surakarta; Magister Ilmu Hukum Program Pascasarjana Universitas Sebelas Maret, hlM. 3.

16 Muchsin, (2003) Perlindungan dan Kepastian Hukum bagi Investor di Indonesia, Surakarta; magister Ilmu Hukum Program Pascasarjana Universitas Sebelas Maret, hlm. 14. yang mengakibatkan tidak terpenuhinya hak-hak tersebut.

Perlindungan Hukum terhadap hasil karya cipta menganut sistem perlindungan otomatis (automatically protection) artinya diperoleh pencipta secara otomatis, tanpa melalui proses pencatatan terlebih dahulu pencipta secara otomatis sudah mendapat perlindungan hukum atas karya cipta nya saat karya tersebut sudah diwujudkan dalan bentuk karya cipta nyata (expression work). ${ }^{17}$ Lebih lanjut dijelaskan bahwa Undang-Undang No.28 Tahun 2014 menganut asas first to use. Akan tetapi bentuk karya itu harus dibuat dalam bentuk nyata (bukan sekedar ide) yang kemudian dipublikasikan. ${ }^{18}$

Meskipun menurut hukum hak cipta perlindungan bersifat otomatis yang diperoleh oleh pencipta sejak ciptaan diwujudkan dalam bentuk nyata, dan tidak harus melalui proses pencatatan, namun apabila dilakukan pencatatan akan lebih baik dan lebih menguntungkan, karena dengan pencatatan, akan ada bukti formal adanya hak cipta jika tidak terbukti sebaliknya. Dengan adanya proses

$17 \mathrm{Ni}$ Ketut Supasti Dharmawan, dkk, (2016), Hak Kekayaan Intelektual , Yogyakarta: Deepublish, hlm. 38- 39

18 Yati Nurhayati, Ifrani, Abdul Halim Barkatullah, dan M. Yasir Said, (2019), "The Issue of Copyright Infringement in 4.0 Industrial Revolution: Indonesian Case", Jurnal Media Hukum, Vol. 26 No. 2, December, hlm.124 
pencatatan jika terjadi peniruan atau penjiplakan karya cipta, si pencipta lebih mudah membuktikan haknya dan mengajukan tuntutan, karena ada bukti formal pencatatan. ${ }^{19}$

Khusus mengenai perlindungan hak pencipta lagu yang lagunya dibuat cover version dan dikomersilkan, perlu adanya perlindungan dan penegakkan hukum yang efektif. Untuk memperoleh pencatatan ciptaan di Kementrian Hukum dan HAM Republik Indonesia, pemohon dapat melakukan pengajuan permohonan melalui tiga alternatif, yaitu :

a. Melalui Direktorat Jenderal Hak Kekayaan Intelektual (Ditjen HKI).

b. Melalui Kantor Wilayah Kementrian Hukum dan Hak Asasi Manusia Republik Indonesia.

c. Melalui Kuasa Hukum Konsultan HKI yang terdaftar. Adapun tahapan-tahapan dalam mendaftarkan hak cipta sebagai berikut $:^{20}$

Alur Pengajuan Permohonan Pencatatan Ciptaan Alur pengajuan permohonan pencatatan ciptaan merupakan tahapan yang harus dilalui oleh pemohon

\footnotetext{
19 Ibid.

20 Yustisia, Tim Visi. (2015). Panduan
} Resmi Hak Cipta Dari Mendaftar, Melindungi, hingga Menyelesaikan Sengketa. Jakarta: Visimedia, hlm. 20. hingga memperoleh bukti/tanda bukti mengajukan permohonan pencatatan ciptaan. Alur permohonan pencatatan ciptaan tersebut dapat digambarkan sebagai berikut :

Gambar 1. Permohonan Pencatatan

Ciptaan

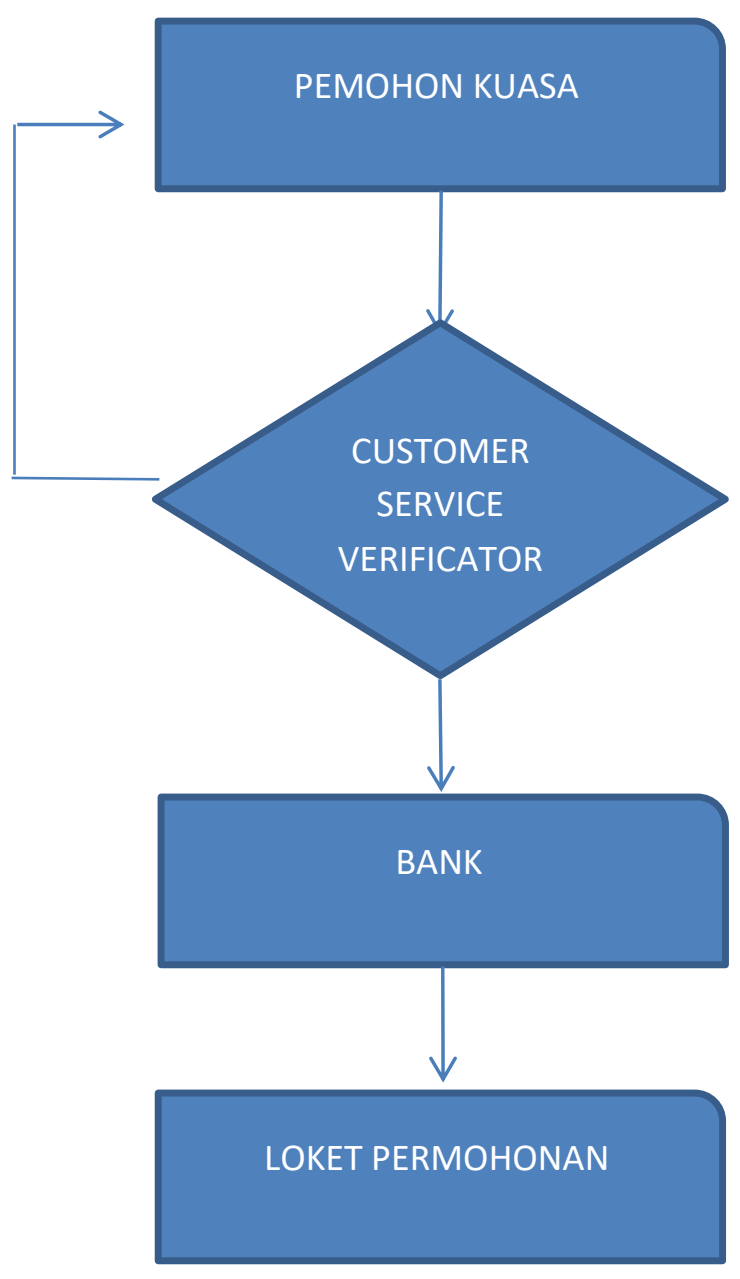

Berdasarkan UUHC, Peraturan Menteri Kehakiman RI Nomor M.01HC.03.01 Tahun 1987 tentang Pendaftaran Ciptaan, dan Keputusan Ditjen HKI Nomor H-01.PR.07.06 Tahun 2004 tentang Petunjuk Pelaksanaan Penerimaan 
Permohonan Hak Kekayaan Intelektual Melalui Kantor Wilayah Departemen dan HAM RI:

1. Pemohon/ kuasa mengisi formulir.

2. Pemohon/ kuasa melampirkan semua kelengkapan permohonan.

3. Verifikator melakukan pemeriksaan kelengkapan permohonan

4. Verfikator memberi perintah bayar.

5. Pemohon melakukan pembayaran.

6. Bank memberikan bukti pembayaran.

7. Pemohon menyerahkan: formulir yang telah diisi lengkap; (2) kelengkapan permohonan, dan (3) bukti pembayaran dari bank.

\section{PENUTUP}

Pertama perlu dibedakan cover lagu dan aransemen. Tindakan cover melalui aransemen ulang lagu milik orang lain tidak termasuk pelanggaran hak cipta sedangkan cover lagu tanpa aransemen dapat dilakukan asalkan memiliki izin lisensi dari pencipta/ pemegang hak cipta dan pembayaran royalti kepada pemegang hak, jika tidak maka cover lagu tersebut merupakan pelanggaran hukum. Hal ini karena cover version yang diunggah ke YouTube mempunyai tujuan dan akibat komersil yang menghasilkan keuntungan.

$$
\text { Perlindungan hukum bagi }
$$

pemegang hak cipta atas pelanggaran hak cipta dibidang musik atau lagu dalam bentuk cover version yang dikomersilkan dapat dilakukan dengan melakukan pencatatan ciptaan dan sengketa dapat diselesaikan melalui arbitrase atau pengadilan niaga.

\section{DAFTAR PUSTAKA}

\section{Buku}

Isnaini, Yusran. (2009). Hak Cipta dan Tantangannya di Era Cyber Space. Bogor: Ghalia Indonesia.

Muchsin, (2003) Perlindungan dan Kepastian Hukum bagi Investor di Indonesia, Surakarta; magister Ilmu Hukum Program Pascasarjana Universitas Sebelas Maret.

Ni Ketut Supasti Dharmawan, dkk, (2016), Hak Kekayaan Intelektua , Yogyakarta: Deepublish.

Soerjono Soekamto dan Sri Mamudji, (2006), Penelitian Hukum Normatif : Suatu Tinjauan Singkat, cet 9, Jakarta : Rajawali Press.

Soerjono Soekanto, (1984), Pengantar Penelitian Hukum, Jakarta: UI Press.

Satjipto Rahardjo, (2000), Ilmu hukum, Bandung: Citra Aditya Bakti, Cetakan ke-V.

Setiono, (2004), Rule of Law (Supremasi Hukum), Surakarta; Magister Ilmu Hukum Program Pascasarjana Universitas Sebelas Maret. 
Philipus M. Hadjon, (1987), Perlindungan Bagi Rakyat diIndonesia, Surabaya: Bina Ilmu.

Yustisia, Tim Visi. (2015). Panduan Resmi Hak Cipta Dari Mendaftar, Melindungi, hingga Menyelesaikan Sengketa. Jakarta: Visimedia.

\section{Jurnal dan Hasil Penelitian}

Anak Agung Mirah Satria Dewi, (2017), "Perlindungan Hukum Hak Cipta Terhadap Cover Version Lagu di Youtube", Jurnal Magister Hukum Udayana, Vol. 6, No. 4.

Yati Nurhayati, (2013), "Perdebatan Antara Metode Normatif Dengan Metode Empirik Dalam Penelitian Ilmu Hukum Ditinjau Dari Karakter, Fungsi, dan Tujuan Ilmu Hukum" Jurnal Al Adl, Vol 5, No 10.

Yati Nurhayati, Ifrani, Abdul Halim Barkatullah, dan M. Yasir Said, (2019) "The Issue of Copyright Infringement in 4.0 Industrial Revolution: Indonesian Case", Jurnal Media Hukum, Vol. 26 No. 2, December.

\section{Website}

Direktorat Jenderal Kekayaan Intelektual "Sejarah Perkembangan Perlindungan Kekayaan Intelektual (KI)", dapat diakses pada https://dgip.go.id/sejarahperkembangan-perlindungankekayaan-intelektual-ki (diakses pada tanggal 20 Oktober 2019 pukul 7.22 WITA)

Hukumonline "Apakah Menyanyikan Ulang Lagu Orang Lain

\begin{tabular}{rrlr}
\hline (diakses & pada & tanggal 20 \\
Oktober 2019 & pukul 7.22 \\
WITA) & & \\
Hukumonline “Apakah & \multicolumn{2}{c}{ Menyanyikan } \\
Ulang Lagu & Orang Lain
\end{tabular}

Melanggar Hak Cipta?” dapat diakses

https://www.hukumonline.com /klinik/detail/ulasan/lt506ec90e 47d25/apakah-menyanyikanulang-lagu-orang-lainmelanggar-hak-cipta/ (diakses tanggal 21 October 2019 pukul 09.30 WITA)

Wikipedia "Kekayaan Inelektual." https://id.wikipedia.org/wiki/K ekayaan_intelektual_diakses pada tanggal 20 Oktober 2019 pukul 07.00 WITA)

Wikipedia "hak cipta" https://id.wikipedia.org/wiki/H ak_cipta (diakses tanggal 21 October 2019 pukul 17.13)

Wikipedia "Lisensi." Dapat diakses secara online https://id.wikipedia.org/wiki/Li sensi diakses tanggal 02 November 2019 pukul 18.48 WITA 